
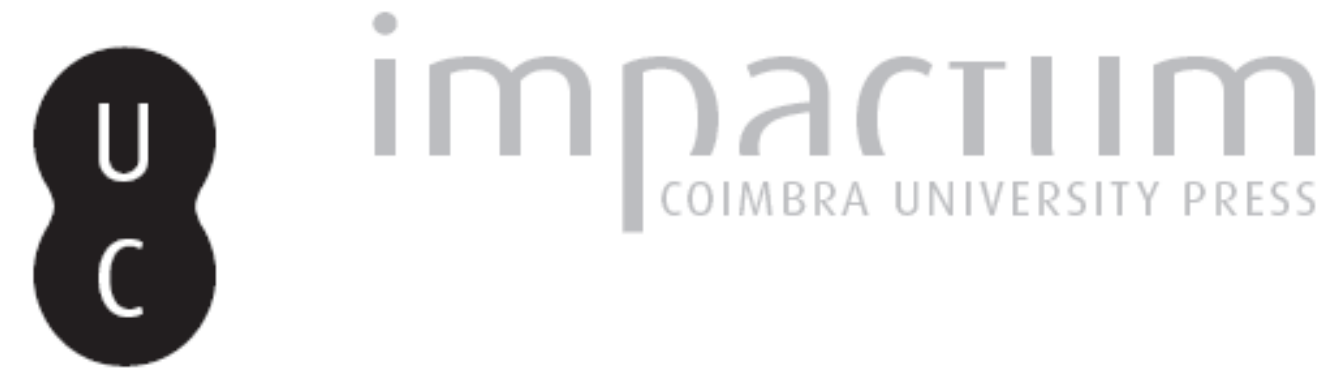

\title{
Plutarch as a source for Epicurean philosophy: another aspect of his nachleben
}

Autor(es): $\quad$ Roskam, G.

Publicado por: International Plutarch Society

URL persistente:

URI:http://hdl.handle.net/10316.2/37627

DOI:

DOI:http://dx.doi.org/10.14195/0258-655X_4_6

Accessed : $\quad$ 26-Apr-2023 07:03:25

A navegação consulta e descarregamento dos títulos inseridos nas Bibliotecas Digitais UC Digitalis, UC Pombalina e UC Impactum, pressupõem a aceitação plena e sem reservas dos Termos e Condições de Uso destas Bibliotecas Digitais, disponíveis em https://digitalis.uc.pt/pt-pt/termos.

Conforme exposto nos referidos Termos e Condições de Uso, o descarregamento de títulos de acesso restrito requer uma licença válida de autorização devendo o utilizador aceder ao(s) documento(s) a partir de um endereço de IP da instituição detentora da supramencionada licença.

Ao utilizador é apenas permitido o descarregamento para uso pessoal, pelo que o emprego do(s) título(s) descarregado(s) para outro fim, designadamente comercial, carece de autorização do respetivo autor ou editor da obra.

Na medida em que todas as obras da UC Digitalis se encontram protegidas pelo Código do Direito de Autor e Direitos Conexos e demais legislação aplicável, toda a cópia, parcial ou total, deste documento, nos casos em que é legalmente admitida, deverá conter ou fazer-se acompanhar por este aviso.

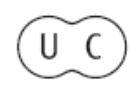


PLOUTARCHOS, n.S. Scholarly Journal of 18

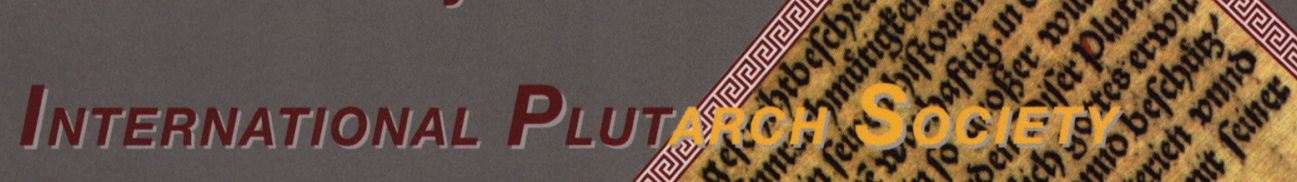

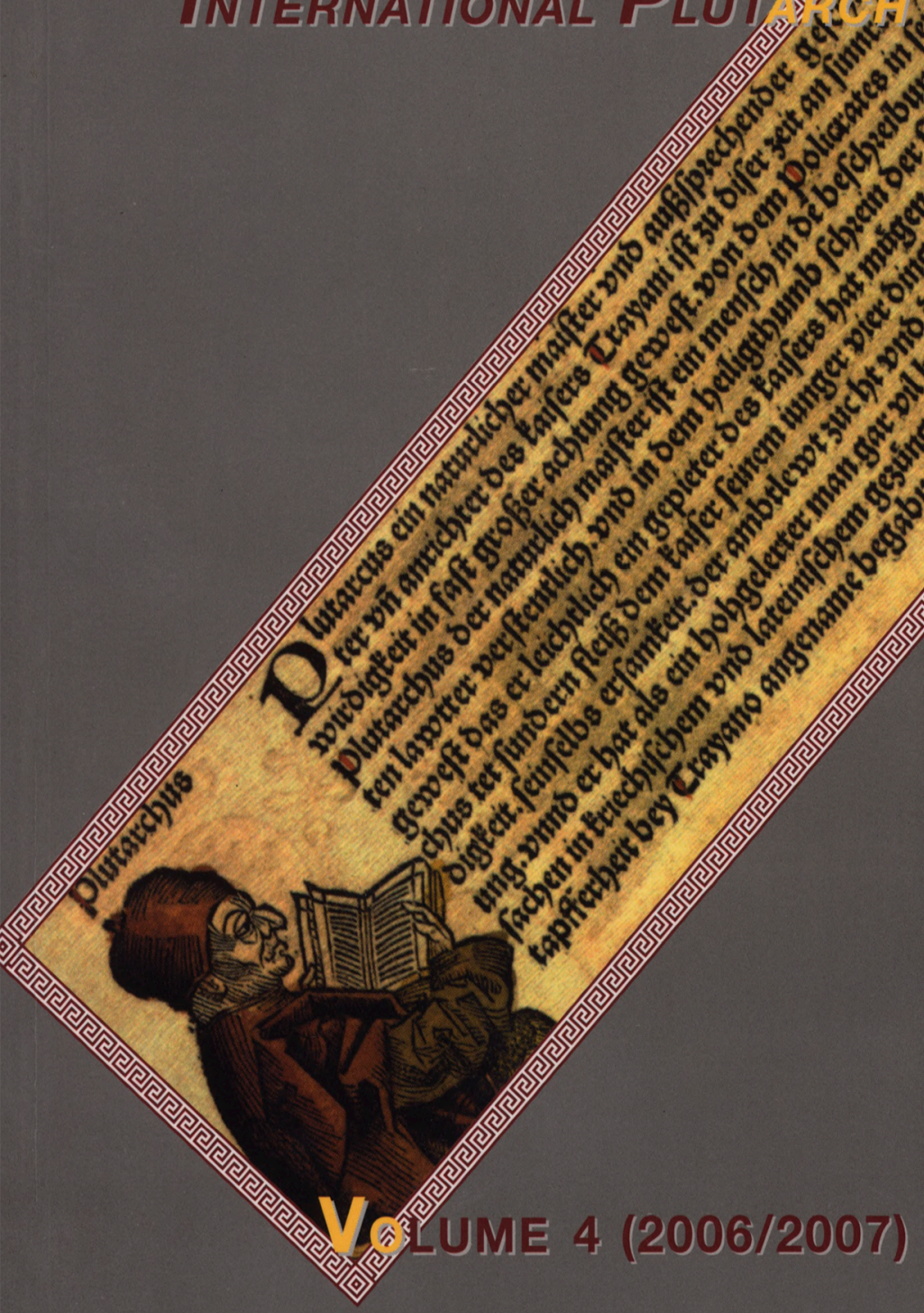

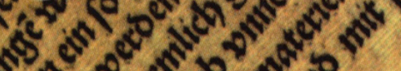

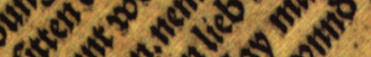

$120^{2} 0^{2} x^{2} x^{2}$

$4 \sin ^{\circ} \cos ^{\circ}$

singes

$0^{2}+0^{2} \mathrm{~s}^{\circ}$

$a^{5} x^{2}$

$s^{5}+\omega^{\circ}$

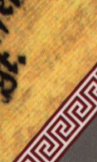

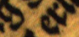

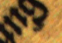




\title{
Plutarch as a Source for Epicurean Philosophy Another Aspect of his Nachleben \\ by \\ G Roskam \\ K.U. Leuven
}

\begin{abstract}
In this contribution I try to answer the question to what extent Plutarch is still important for us today as a source for Epicurus' socio-political thinking. On the basis of a reasoned classification of all the relevant passages, I examine the strategies which Plutarch uses in the selection and presentation of the subject matter and in his verbatim quotations from Epicurus' texts.
\end{abstract}

Non omnis moriar Horace, carm. 3,30,6

1. Plutarch never died. No doubt his body has long been decomposed and rendered to Demeter, and perhaps his soul meanwhile faded away on the moon (cf., at least, De facie 943Asqq.). But even after so many centuries, his mind is still as brilliant as the sun. This appears not only from his own works, but also from the immense influence they exerted on later authors. It is well known indeed that Plutarch's works, long before they have been collected and introduced into one corpus $\backslash$ have been used again and again by later generations ${ }^{12}$. Already in Antiquity, authors such as Aulus Gellius 3 ,

1 On the gradual growth of the Corpus Plutarcheum (esp. regarding the Moralia), see J. IRIGOIN, 'Histoire du texte des "EEuvres morales" de Plutarque', in the general introduction of the Budé-edition of Plutarch's Moralia, Paris, 1987 and F. FrAZIER, 'Le corpus des Euvres Morales, de Byzance à Amyot. Essai de synthèse', in: Pallas, 67 (2005) 77-93.

General studies of Plutarch's Nachleben include R. HIRZEL, Plutarch, Leipzig, 1912, $74-$ 199; K. ZIEGLER, Plutarchos von Chaironeia, in: RE 21,1, Stuttgart, 1951, 947-962; C.J. GIANAKARIS, Plutarch, New York, 1970, 129-150; I. GALLO (ed.), L'eredità culturale di Plutarco dairAntichità al Rinascimento. Atti del VII Convegno plutarcheo. MilanoGargnano, 28-30 maggio 1997, Napoli, 1998; J. SiRINELl, Plutarque de Chéronée. Un philosophe dans le siècle, Paris, 2000, 443-474.

3 F. STOK, 'Plutarco nella letteratura latina impériale', in: I. GALLO (ed.), L'eredità culturale di Plutarco [cit. n. 2], 60-71 and L. VAN DER STOCKT, 'Plutarch's Anger in Aullus Gellius, Noctes Atticae, I, 26', in: J. RIBEIRO FERREIRA - D. FERREIRA LEÃO (eds.), Os fragmentos de Plutarco e a recepção da sua obra, Coimbra, 2003, 143-156. 
Favorinus ${ }^{4}$, and Apuleius ${ }^{5}$ were familiar with (important aspects of) Plutarch's thinking, and he also received a - rather limited - place in the great commentaries of the Neoplatonists ${ }^{6}$. Early churchfathers, too, appreciated his thinking and often drew inspiration from his moral advice 7 , and from the Renaissance on, both Moralia and Lives continued to fascinate and influence a public of cultivated readers.

2. Plutarch's Nachleben has been intensively studied. And yet, there is a lot of work that still has to be done. Time and again, new authors appear to have been influenced by Plutarch's works, and the results of earlier studies can often be completed with additional material. The general focus of such reception studies is nearly always on the question which influence Plutarch exerted on one or more later authors. Typical questions are: to what extent $X$ proves to have been familiar with Plutarch's œuvre? Was Y primarily interested in the Lives or the Moralidi Which Plutarchan motifs or philosophical convictions return in the works of $Z$, and how does he/she use or modify them? Is Plutarch merely used as a source of information or rather as a discussion partner? It is clear that such investigations throw an interesting light on the important place which Plutarch occupied in the cultural life of later centuries.

In this contribution, I would like to draw attention to a completely different aspect of Plutarch's Nachleben, which is as such far less frequently thematized and which at first sight perhaps also looks

4 Cf. J. Opsomer, 'Favorinus versus Epictetus on the Philosophical Heritage of Plutarch. A Debate on Epistemology', in: J. Mossman (ed.), Plutarch and his Intellectual World. Essays on Plutarch, London, 1997, 17-39.

5 See P.G. Walsh, 'Apuleius and Plutarch', in: H.J. Blumenthal - R.A. Markus (ed.), Neoplatonism and Early Christian Thought. Essays in honor of A. H. Armstrong, London, 1981, 20-32; V. HuninK, 'Plutarch and Apuleius', in: L. DE Blois - J. Bons - T. KesSels - D. M. SCHENKEVELD (eds.), The Statesman in Plutarch's Works. Proceedings of the Sixth International Conference of the International Plutarch Society. Nijmegen/Castle Hernen, May 1-5, 2002. Voi. I: Plutarch's Statesman and his Aftermath: Political, Philosophical, and Literary Aspects, Leiden-Boston, 2004, 251-260; and W.H. Keulen, 'Lucius' Kinship Diplomacy: Plutarchan Reflections in an Apuleian Character', in: Ibid. 261-273.

6 See, e.g., A. Rescigno, 'Proclo lettore di Plutarco?', in: I. GALlo (ed.), L'eredità culturale di Plutarco [cit. n. 2], 111-141 and F. FERRARI, 'Plutarco in Siriano, In Arisi. Metaph. 105,36ss.: lo statuto ontologico e la collocazione metafisica delle idee', in Ibid. 143-159.

7 This aspect of his Nachleben is too rarely discussed. See nonetheless M. LA Matina, 'Plutarco negli autori cristiani greci', in: I. GALlo (ed.), L'eredità culturale di Plutarco [cit. n. 2], 81-110; A.-I. Bouton-Touboulic, 'Présences des Moralia de Plutarque chez les auteurs chrétiens des IVe et Ve siècles', in: Pallas 61 (2005) 95-113; S. MORLET, 'Plutarque et l'apologétique chrétienne: la place de la Préparation évangélique d'Eusèbe de Césarée', in: Pallas, 67 (2005) 115-138. 
somewhat less spectacular. My starting point is a fairly general question: what is the importance Plutarch can still have for us today ${ }^{8}$ ? It is clear of course that such a question is extremely difficult to answer, and that each answer is doomed to be at best partial and personal, at worst biased and simply wrong. Plutarch's work is far too differentiated to summarize its importance in some vague and generalizing phrases, and the issues of our own times are too complex to connect them in an oversimplified way with particular aspects of Plutarch's thinking. As a result, the focus of our starting point has to be more narrowly circumscribed.

Accordingly, I propose to deal with one aspect of this general question: to what extent is Plutarch still important for us today as a source for Epicurean philosophy? This reformulation and limitation of the initial question entails interesting opportunities for more detailed research. It is clear that this research will only enlighten a small part of a much greater whole, offering as it were one piece of a puzzle which contains thousands of pieces. But even this separate, minor piece has to be put on its proper place if one once wishes to enjoy the picture offered by the final result.
Furthermore, one should note that this reformulation of the initial question also opens up a broader field than that of traditional reception studies. For whereas the latter usually focus on two poles (viz. Plutarch and a later author), we now have to deal with three (Epicurus, Plutarch, and we). At first sight, such an investigation seems to devaluate Plutarch as a mere intermediary, who is not studied for his own sake but merely in so far as he contributes to our understanding of Epicurus. In other terms, Epicurus' Nachleben seems to eclips that of Plutarch. This prima facie evaluation, however, has to be corrected: a correct understanding of Plutarch's importance as a source for Epicurean philosophy presupposes not merely a thorough familiarity with the Epicurean view, but also a careful analysis of the works and philosophy of Plutarch. And if both poles should receive equal attention, the results of our study concern Plutarch's Nachleben no less than that of Epicurus.

There is no need to labour the obvious point that Plutarch is for us an important source for Epicurean philosophy ${ }^{9}$. He is often quoted in secondary literature on Epicureanism, and he more than once offers the crucial (if not only) information on a certain topic or

Interesting reflections on this topic can for instance be found in R. HIRZEL, o.c. [n. 2], 200-206; cf. also C.J. GIANAKARIS, o.c. [n. 2], 144-150.

See, e.g., J.P. HershBell, 'Plutarch and Epicureanism', in: ANRWII, 36, 5, Berlin - New York, 1992, 3357-3361; J. BouloGNE, Plutarque dans le miroir d'Epicure. Analyse d'une critique systématique de l'épicurisme, Villeneuve d'Ascq, 2003, 13-18. 
author $^{10}$. The information which he offers covers the whole domain of Epicurean philosophy, from canonic to metaphysics, from epistemology to theology, from physics to ethics. The great diversity of this material illustrates Plutarch's massive erudition, but also confronts us with a difficult dilemma. Either, we can give attention to all elements, in order to arrive at a rapid overview of the most important characteristics of Plutarch's use and presentation of Epicurean doctrines. This alternative offers a more general perspective and can claim to be exhaustive, but it quickly risks to become superficial and moreover will hardly add anything to our knowledge. The second alternative is to fix all our attention on one specific domain of Epicurean philosophy. This will of course yield far less comprehensive results, but can also lead to more detailed conclusions and new insights. It is clear that in this context, the latter alternative presents itself as the most attractive. This entails a second limitation of the initial question, which can finally be reformulated as: to what extent is Plutarch still important for us today as a source for Epicurus' sociopolitical philosophy? It is to this question that I would like to turn in the remainder of this contribution.

3. Even though our focus on one specific domain implies a considerable limitation, there is still much relevant material to be found in the Corpus Plutarcheum. This even more illustrates Plutarch's impressive $\pi \alpha 1 \delta \varepsilon i ́ \alpha$ and his importance as a source for Epicurean philosophy. Not all passages are equally interesting, to be sure. Sometimes they merely contain vague paraphrases which hardly contribute to our knowledge. There are, however, also verbatim quotations from Epicurus' own writings. The great variety of the material thus requires a certain structuring. In the following list, the relevant passages are classified into four main categories:

a) verbatim quotations of self-contained units

[1] De and. poet. $37 \mathrm{~A}=$ fr. 548 Us.

[2] Non posse 1090CD = fr. 532 Us.

One should merely recall his importance for the reconstruction of Colotes' lost work

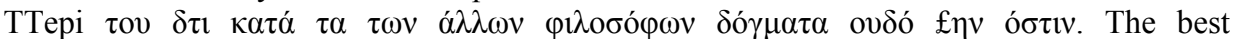
reconstruction of the content of this work is still to be found in the valuable study of $\mathrm{R}$. Westman, Plutarch gegen Kolotes. Seine Schrift “Adversus Colotem " ais philosophiegeschichtliche Quelle, Helsingfors, 1955, 40-93. Smaller fragments from his works Against Plato s Lysis and Against Plato s Euthydemus have been edited by W. CRÕNERT (.Kolotes und Menedemos. Texte und Untersuchungen zur Philosophen- und Literaturgeschichte, Leipzig, 1906, 163-170); cf. also M. ERLER, 'Die Schule Epikurs', in: H. Flash AR (ed.), Die Philosophie der Antike, Band 4: Die Hellenistische Philosophie, Basel, 1994 (Grundriss der Geschichte der Philosophie, begründet von Friedrich Ueberweg), I, 236-238. 
[3] Non posse $1097 \mathrm{CD}=$ fr. 183 Us.

[4] Non posse $1105 \mathrm{E}=$ fr. 213 Us.

[5] Adv. Colot. 1125C = fr. 554 Us.

[6] Adv. Colot. 1127D = fr. 18 Us.

[7] De lot. viv. 1128A [title] = fr. 551 Us.

and cf. [33].

b) introduction of technical terms and concepts

[8] De tuenda $135 \mathrm{CD}=$ fr. 8 Us.

[9] Quaest. conv. Ill, 6, 655C = fr. 426 Us.

[10] Maxime cum principibus $778 \mathrm{C}$ $=$ fr. 544 Us.

[11] De Stoic, rep. $1033 \mathrm{C}=$ fr. 426 Us.

c) paraphrases

- rather loose paraphrases, reminiscences, allusions

[12] De tranq. an. $465 \mathrm{~F}-466 \mathrm{~A}=\mathrm{fr}$. 555 Us.

[13]Deam. pro!. 495A = fr. 527 Us.

[14] Non posse $1095 \mathrm{CD}=$ fr. 5 Us.

[15] Non posse 1097A = fr. 544 Us.

[16] Non posse $1097 \mathrm{C}=$ fr. 559 Us.

[17] Non posse $1099 \mathrm{~F}-1100 \mathrm{~A}=$ frs. 178 and 549 Us.

[18] Non posse 1104B = fr. 534 Us.

[19] $A d v$. Colot. HUB $=546$ Us.

[20] Adv. Colot. 1123A = fr. 528 Us.

[21] Adv. Colot. $1125 \mathrm{C}=$ frs. 8 and 556 Us.

[22] Adv. Colot. 1127A $=$ frs. $6^{*}$ and 8 Us.

[23] Adv. Colot. 1127DE = fr. 8 Us.
[24] Adv. Colot. 1127E = fr. 558 Us.

[25] De lat. viv. 1129B = fr. 524 Us.

[26] Pyrrh. 20,3 = fr. 552 Us.

and cf. [8] and [10],

- paraphrases which remain close to Epicurus' original words

[27] Non posse 1087B = fr. 552 Us. [28] Adv. Colot. 1127D = fr. 134 Us. and cf. [21],

d) other

[29] Defrat. am. 487D = fr. 178 Us.

[30] Non posse $1097 \mathrm{AB}=$ fr. 194 Us.

[31]Adv.Colot. $1126 \mathrm{C}$ (p. 123,22-25 Us.)

[32] Adv. Colot. 1126EF = fr. 194 Us.

[33]Adv. Colot. 1127AB = fr. 560* Us.

This list offers a representative picture of the material which we have at our disposal. The order in which the passages are listed does not imply a degree of importance. Some passages which are classified as paraphrases, offer much more important information than several verbatim quotations. The last category ("other") primarily — though not exclusively — contains passages which refer to several actions and decisions of Epicurus that directly or indirectly illustrate aspects of his socio-political philosophy. As such, they sometimes prove to provide as valuable information as verbatim quotations.

A classification of passages such like the one offered above is not always easy. Especially the third category ("para- 
phrases") is often problematic, as it is not always clear how close a paraphrase is to the original words. Most passages presumably contain rather loose paraphrases, which point in quite general terms to the Epicurean position. Occasionally, however, it seems at least plausible that Plutarch's phrasing remains very close to that of Epicurus, and that one could with good reason classify the passage among the first category ("verbatim quotations"). In an attempt to offer a partial solution to this problem, I have distinguished between loose paraphrases and paraphrases which remain close to Epicurus' original words, but it is clear of course that there remains a twilight zone where compelling evidence is absent. All in all, 1 am confident that the above classification of most passages can be accepted without problem, even though the place of one or two could appear doubtful to some people.

Finally, one should note that different categories can occasionally be combined. A paraphrase can gradually turn into a literal quotation (e.g. [21]), or can contain technical terms (e.g. [8] and [10]). Plutarch's works are in the end far too rich and diverse to be imprisoned in preconceived and schematic categories. Nonetheless, the above classification remains useful as a structured introduction to the relevant material, even though it is not the most important result of our study.

4. We can now turn to our central question and examine how these passages contribute to our understanding of
Epicurus' socio-political thinking. It is very important to note from the very beginning that the information which they offer should not be regarded as a direct gate to the Epicurean point of view. Plutarch always regarded the Epicurean doctrines which he mentions through the lense of his own Platonism. This perspective strongly conditioned the way in which he selected and presented his material. As a direct result, a correct evaluation of the relevant passages presupposes a careful analysis of Plutarch's own auctorial strategies and purposes.

Plutarch's selection and presentation of Epicurean tenets nearly always serves a polemical purpose. In that respect, it is interesting to note that from the thirtythree passages, twenty-five are to be found in anti-Epicurean polemical works. In nearly all other cases, too, traces of polemical attacks can be detected. Even in [29], where Plutarch praises the fraternal love of Epicurus' brothers, and explicitly adds that both Epicurus, who inspired this devotion, and his brothers, who felt it, should be admired, he in passing utterly rejects

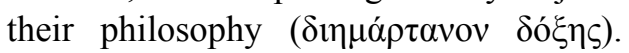
This observation has an important implication: there appears to be a great difference between Plutarch's purpose and that of the modem reader who uses his work as a source for Epicureanism. The latter indeed is looking for information that can add to his understanding of Epicurus' position, whereas the former merely wishes to show the great defects of Epicurean philosophy, and thus often 
deliberately obstructs correct understanding rather than contributing to it.

Plutarch's polemical intentions have important consequences for the evaluation of the material he offers. Three aspects will be examined somewhat more in detail in what follows:

- the choice of the subject matter: to which aspects of Epicurus' sociopolitical thinking Plutarch gives attention? In which topics is he especially interested, and which does he rather avoid? Which consequences does this choice have for his reliability as a source for Epicureanism?

- the presentation of the subject matter: how does Plutarch present the Epicurean doctrines he wants to discuss? Which polemical strategies condition his presentation, and which implications this again has for his reliability as a source?

- the use of verbatim quotations: when does Plutarch prefer to paraphrase the position of his philosophical opponent, and when does he take the strategical decision to quote him at length? How is this decision influenced by his polemical intentions?
4.1.The choice of the subject matter. Plutarch has a strong preference for the more "extreme" doctrines of Epicurus. This is clearly a direct consequence of his polemical purpose. By presenting Epicurus' view as oversimplified and extreme, he disqualifies his opponent in advance, which makes subsequent refutation much easier of course. This approach is based on two complementary eristic strategies.

First, Plutarch often makes Epicurus' position seem much more extreme and radical than it actually is. A particularly illustrative example is Plutarch's reference to Epicurus' negative position with regard to participation in political life.

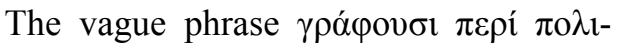
$\tau \varepsilon i \alpha \varsigma^{*} \ddot{i} v \alpha \mu$ í $\pi \circ \lambda \imath \tau \varepsilon v \omega \mu \mu \theta \alpha$ [22] is a case in point (cf. also [21] and [24]). Plutarch knew very well that Epicurus' position was far more nuanced, and that several exceptions to this rule were possible ${ }^{11}$. He himself even mentions, in a famous passage [12], Epicurus' conviction that ambitious people should enter politics, as in their case, inactivity would prevent them from fulfilling their desires and thus throw them into confusion .

11 They have been discussed in greater detail by D.P. FOWLER, 'Lucretius and Politics', in: M. GRIFFIN - J. BARNES (eds.), Philosophia Togata. Essays on Philosophy and Roman Society, Oxford, 1989, 126-133.

12

Cf. A. GRILli, 'Considerazioni sul fr. 555 Us. di Epicuro', in: G. GiannANTONI - M. GigANTE (eds.), Epicureismo greco e romano. Atti del congresso internazionale, Napoli, 19-26 maggio 1993, Napoli, 1996, 377-386. The passage should be understood in the context of an attack against Democritus; cf. G. ROSKAM, 'The Displeasing Secrets of the Epicurean Life. Plutarch's Polemic against Epicurus' Political Philosophy', in: A. 
And yet, he usually prefers to ignore such nuances and introduce Epicurus' position as an unqualified rejection of politics. It is clear of course that this presentation mainly suits Plutarch's own polemical intentions: a radical and unqualified view is much easier to be refuted than a nuanced position. At the same time, however, Plutarch's polemical purpose strongly interferes with the aims of a modern reader who is trying to improve his insight in Epicurus' position. General paraphrases such as those discussed above may reflect the general tendencies of Epicurus' political thinking, to be sure, but they have to be completed by other sources. Taken on their own, they offer a highly biased and misleading picture of Epicurus' position. In this particular case, then, a correct insight into Plutarch's polemical techniques appears to disqualify him as a reliable source for Epicureanism.

The second strategy consists in focusing on the most radical conse- quences of Epicurus' thinking. In this case, the extreme position is not the result of Plutarch's oversimplified presentation, but should indeed be traced back to Epicurus himself. A beautiful example is Epicurus' notorious evaluation of parental love for one's offspring ( $\varphi \imath \lambda 0 \sigma \tau o \rho \gamma i ́ \alpha)$ as unnatural. Epicurus of course had his arguments to adopt such a view. He did not deny that parents actually love their children, but argued that their love was based on a hedonistic calculus, rather than on natural feelings. This view, which was later defended by Demetrius $\mathrm{Laco}^{13}$, is merely one application of Epicurus' much more general conviction that man is not a social being by nature ${ }^{14}$ and that all feelings of love are based on personal benefit ${ }^{15}$. Plutarch, however, prefers to omit this more general perspective, and merely presents Epicurus' tenet in all its radicalness (in [13]), adding that such a position is at odds with widely accepted beliefs (see

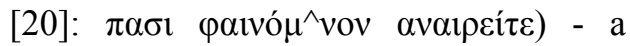
hardly necessary observation of course.

CASAnova (ed.), Plutarco e l'età ellenistica. Atti del convegno internazionale di studi (Firenze, 23-24 settembre 2004), Firenze, 2005, 351-368.

13 According to Demetrius Laco, the words 'not natural' in Epicurus' characterization of parental love for offspring should be understood as 'not necessary' ( $\mu$ í $\varphi v ́ \sigma \alpha$ being tantamount to $\mu$ ' $\kappa \alpha \tau$ ' $\alpha v \alpha ́ \gamma \kappa \eta v)$; cf. E. PUGLIA, 'L'amore per i figli nella dottrina di Epicuro (Dem. Lac., PHerc. 1012, coll. LXVI 5 - LXVIII)', in: B.G. MANDILARAS (ed.), Proceedings of the XVIII International Congress of Papyro logy. Athens 25-31 May 1986, Athens, 1988, 249-255.

14 Cf., e.g. Themistius, Orat. XXVI, 324a Downey - NoRman (= fr. 551 Us.): кa'ı $\varepsilon \theta \varepsilon \tau o$

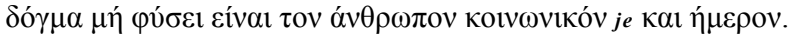

15 Lactantius, inst. 3,17,42 (= fr. 540 Us.): dicit Epicurus [...] neminem esse, qui alterum diligat, nisi sua causa; cf. also Cicero, fam. 7,12,2. 
Again, such positions are much easier to refute than less controversial tenets, and hardly require circumstantial arguments. A brief and suggestive remark, or a simple appeal to common sense, or even the expression of feelings of indignation, often yield much better results than elaborate theoretical reflections. It is not surprising that attacks against this Epicurean doctrine can also be found in other authors ${ }^{16}$. Such parallels show that this doctrine was regarded as one of the more vulnerable aspects of the Epicurean view. Once again, however, such attacks are of limited value as a source for our knowledge of Epicurus' position, as they merely mention a radical tenet of Epicurus, without any further reference to his argumentation. Again, Plutarch's purposes thus prove to interfere with those of the contemporary reader, as the information which most interests the latter, is carefully omitted by the former. What rests is an unattractive skeleton of dry tenets, stripped of all the flesh and organs of lively philosophical argumentation.
As important as the analysis of the themes that are discussed by Plutarch is a study of what he omits. In this case too, Plutarch's polemical intentions make their influence felt. Several interesting aspects of Epicurus' philosophy are hardly mentioned by Plutarch. He never deals with Epicurus' attack on ambition as a vain and unlimited desire that can never be satisfied ${ }^{17}$. He hardly refers to the great importance Epicurus attached to friendship, and the few allusions to the topic (viz. the notorious problem of the relation between friendship and usefulness in [19], and the quo-

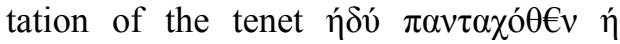

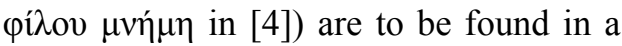
polemical context where they are not thematized for their own sake. The Epicurean doctrine of security as a necessary condition for $\alpha \tau \alpha \rho \alpha \xi \alpha^{19}$ is likewise absent in Plutarch's works. Epicurus' philosophy of law and justice, finally, which receives much attention in

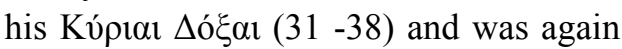
discussed by Hermarchus and Colotes,
16

See, e.g., Epictetus, 1,23,3-10 (= fr. 525 Us.); 2,20,25 (= fr. 511 Us.); Cicero, Att. 7,2,4 (= fr. 528 Us.).

17 A vague allusion can perhaps be found in Non posse 1101B, where $\delta$ o

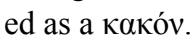

18 On Plutarch's criticism of Epicurus' doctrine of friendship, see esp. J. BOULOGNE, o.c. [n. 9], 199-213.

19 On the doctrine see A. BARIGAZZI, 'Sul concetto epicureo della sicurezza estema', in:

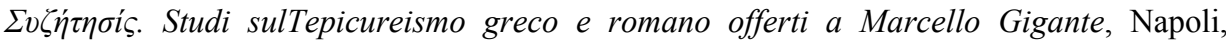
1983, I, 73-92; cf. also M. SCHOFIELD, 'Social and Political Thought', in: K. ALGRA-J. BARNES - J. MANSFELD - M. SCHOfIEld (eds.), The Cambridge History of Hellenistic Philosophy, Cambridge, 1999, 748sqq. 
is rather neglected by Plutarch ${ }^{20}$. Where he alludes to this part of Epicurus' sociopolitical thinking (viz. [2], [6], [18], [23], [24], and [28]), he never discusses the matter at length and more than once offers a particularly misleading interpretation of Epicurus' position.

All these omissions are highly significant, as they illustrate Plutarch's polemical purposes no less than his biased presentation of other Epicurean tenets. A discussion of more fundamental questions and perspectives has to yield to the refutation of oversimplified generalisations and/or extreme doctrines. The general philosophical framework in which Epicurus' position should be placed and which often qualifies more particular aspects of his view, is almost completely omitted. As a result, the contemporary reader who aims at a better understanding of Epicurus' philosophy, will not find the information which he most needs in Plutarch's works.
4.2. The presentation of the subject matter. Plutarch does not always present his material in a neutral, objective way. His references to, or reformulations of the Epicurean doctrines are often conditioned by his own polemical purposes. Again, he makes use of several eristic strategies.

First of all, he more than once isolates Epicurus' words from their original context $^{21}$. This is the case, for instance, with Epicurus' notorious advice of XdOc $\beta i \omega \sigma \alpha \varsigma^{*}$ [7]. Plutarch devotes a whole work to the refutation of this maxim, without giving any information about its original context, its precise - and, no doubt, nuanced - meaning, the arguments which Epicurus brought forward in support of it, or the possible restrictions or exceptions that he accepted ${ }^{22}$. As a direct result, Plutarch's anti-Epicurean attacks in De latenter vivendo may contain much interesting information about his own Platonic view, but hardly throw light on Epicurus' own

On the important place of law and justice in Epicurus' political thinking, see esp. R. MÜLLER, Die Epikureische Gesellschaftstheorie, Berlin, 1974; ID., 'Konstituierung und

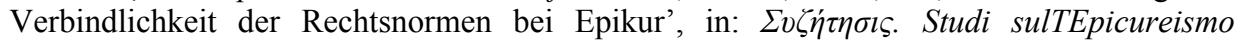
greco e romano offerti a Marcello Gigante, Napoli, 1983, I, 153-183; V. GoLDSCHMIDT, La doctrine dEpicure et le droit, Paris, 1977.

21 Even if he himself blames Colotes for exactly the same polemical strategy (Adv. Colot. 1108D).

22 The best discussions of Plutarch's De latenter vivendo are A. BARIGAZZI, 'Una declamazione di Plutarco contro Epicuro: il De latenter vivendo', in: Prometheus 16 (1990)

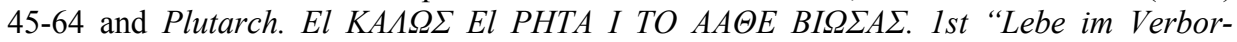
genen " eine gute Lebensregel? Eingeleitet, libersetzt und mit interpretierenden Essays versehen von U. BERNER, R. FELDMEIER, B. HEININGER und R. HIRSCH-LUIPOLD, Darmstadt, 2000. A good status quaestionis also in I. GALlo, Plutarco. Se sia ben detto vivi nascosto, Introduzione, testo critico, traduzione e commento, Napoli, 2000. 
position. Another example of the same strategy is the lengthy quotation of Epicurus' grateful words to his friends about their material support [3]. Their behaviour in sending grain is called

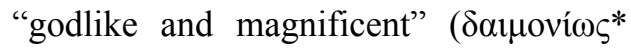
TÉ $\left.\kappa \alpha i ́ \mu^{\wedge} \gamma \alpha \lambda \mathrm{o} \pi \rho \beta \pi \omega \varsigma^{*}\right)$, and the tokens of their goodwill to him are regarded as

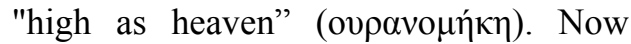
such terms had their own meaning in an orthodox Epicurean point of view. It is by introducing them into a completely different perspective, and opposing them to great political achievements, that they begin to sound strange and ridiculous. A similar strategy is perhaps also at work in [14]. There, Plutarch recalls how Epicurus advised even culti-

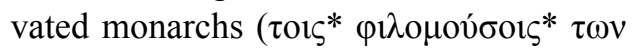
$\beta \alpha \sigma \imath \lambda \dot{\varepsilon} \omega v)$ to "put up with recitals of stratagems and with vulgar buffooneries at his drinking parties sooner than with the discussion of problems in music and poetry" (transi. Einarson-De Lacy). Even if this paraphrase probably presents a certain similarity with Epicurus' original position, it also shows great differences with Philodemus' advice in De bono rege (col. XVI, 14 - XXI, 39 Dorandi $\left.^{23}\right)$. These differences can partly be explained by Philodemus' greater interest in poetry and music, to be sure, but it nonetheless remains rather unlikely that Epicurus advised kings to be licentious "as if he were writing to Sardanapalus"

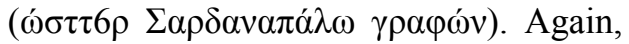
by isolating Epicurus' advice from the context to which it belongs, Plutarch creates a strongly biased picture of his opponent's actual position.

Other polemical attacks rest on Plutarch's shrewd use (or interpretation) of one particular term. He refers, for instance, to the Epicurean conviction that to be king is a fault ( $\alpha \mu \alpha \rho \tau i ́ \alpha v$; [21]). Now it is true of course that Epicurus did not regard the life of a king as an ideal - although he left open the possibility that in exceptional cases even such a life may offer the security that can lead to happiness (RS 6). But the sharp moral rejection which Plutarch's formulation seems to imply, is no doubt alien to Epicurus. It is extremely unlikely in any case, that Colotes will have defended such a view in his work, which was addressed to Ptolemy $\mathrm{II}^{24}$. The term $\alpha \mu \alpha \rho \tau i ́ \alpha v$ reflects Plutarch's polemical intentions rather than Epicurus' own view. Epicurus' supposed characterisation of the life of a king as a fault is completed by his advice to avoid $\sigma v \mu \beta 10 v v$ $\beta \alpha \sigma \imath \lambda \beta \ddot{\sigma} \sigma \mathrm{r}$ (in [22]). Once again, such paraphrase might show superficial resemblance with the Epicurean point of view, but again it is also suggestive of a radicalness that is thoroughly unin: JRS, 55 (1965) 166-167 and E. Asmis, 'Philodemus's Poetic Theory and On the Good King According to Homer in: Cl Ant, 10 (1991) 35-37.

Cf. R. Westman, o.c. [n. 10], 41. 
Epicurean. For indeed, Epicurus no doubt preferred living in his own Garden, far away from the troubles at the royal Court, but there were also Epicureans who actually did live at the Court ${ }^{25}$. Epicurus' advice was at least less absolute and unqualified than Plutarch's formulation implies. Misrepresentations such as these often rest on small terminological inaccuracies, but they make Epicurus' position seem more radical than it actually is.

Another interesting example where Plutarch's attack is based on one term can be found near the end of Adversus Colotem (see [28]). There, Plutarch paraphrases Epicurus' advice to Idomeneus

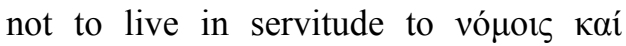
$\delta$ ó $\xi \alpha 1$. This formulation probably remains close to Epicurus' original words, but whereas Epicurus used the term vóno to denote "custom"26, Plutarch interprets it as meaning "law", thus ascribing to Epicurus a subversive position which the latter obviously did not endorse. It is clear that Plutarch can only do this by isolating the passage from its surrounding context. Different eristic strategies are thus often combined in order to attain the best polemical results. Needless to say that in such cases, the information which Plutarch offers is even less reliable.
A different eristic strategy that concerns Plutarch's presentation of the material is his use of small and subtle additions in order to make Epicurus appear in an unfavourable light. This strategy often occurs when Plutarch refers to concrete actions of Epicurus himself. When alluding to the well-known conflict between Metrodorus and Timocrates (in [31]), Plutarch specifies that Epicurus sent

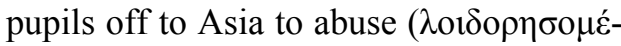

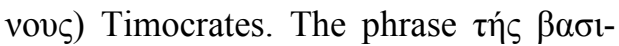

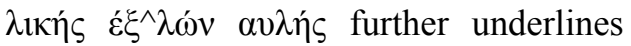
this merely negative motivation of Epicurus' decision, whereas the addition $\alpha \delta \varepsilon \lambda \varphi$ ó $\propto$ óv casts a dark shade over the family relations in the Garden. An even clearer example of the same strategy is to be found in [30] and [32], on Epicurus' praise of Metrodorus' trip to the Peiraeus in order to help Mithres. The indefinite pronoun $\tau$ iví in [32] suggests that Mithres was a rather unimpor-

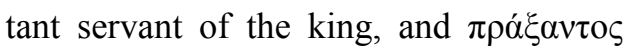

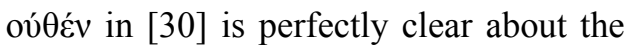
poor results which Metrodorus obtained. Although the text of Philodemus' $\Pi \rho \alpha \gamma \mu \alpha \tau € i \alpha$ is too fragmentary to base secure conclusions on it, it remains safe to say that Plutarch's presentation of what happened is strongly conditioned by his own polemical purpose. 11 (1981) 41-101, esp. 43-47) and Philonides (whose life is related in PHerc. 1044; see 1. GALlo, 'Vita di Filonide epicureo \{PHerc. 1044)', in: ID., Frammenti biografici da papiri. Vol. 2: La biografia dei filosofi, Roma, 1980, 23-166). 
A particularly clever strategy, finally, consists in expressing Epicurus' position by means of poetic quotations. A beautiful example can be found near the beginning of Non posse (see [27]), where Plutarch applies two verses from Homer's Odyssey to the Epicurean point of view. A paraphrase of Epicurus' position, which probably remains close to the latter's original words, is added in order to lend further credibility to the highly biased picture. An even more illustrative example occurs in [13], where a quotation from a comic

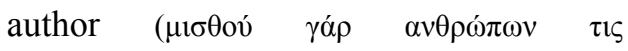

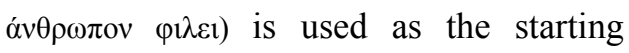
point of a reference to Epicurus' position. Twice, the poetic quotations directly lead to a presentation which challenges the moral standards of Epicurus' philosophy. Poetic quotations, then, are not always introduced for the sake of ornatus, but prove also efficient in a polemical context.

\subsection{The use of verbatim quotations. In} the great majority of cases, Plutarch prefers to paraphrase Epicurus' position rather than quoting him in full. It is clear of course that such paraphrases usually offer the most interesting opportunities for polemical attacks. They can give ample opportunity to use the strategies discussed above in 4.1 and 4.2, and they often make it easier to allude to problems without making them explicit, and to suggest polemical conclusions without having the need to argue for them. And yet, Plutarch more than once takes the strategical decision to quote Epicurus at length. Such quotations usually remain rather brief, and are isolated from their original context. In all cases, moreover, Plutarch's use of quotations is highly functional.

It is no coincidence that nearly half of all relevant verbatim quotations are to be found in Non posse. This is closely connected with the general eristic strategy of the whole work. Plutarch attempts to show that one cannot live pleasantly if one endorses the Epicurean philosophy. Now such a strategy of course presupposes continuous reference to the doctrine of the opponent, and in such a context, verbatim quotations offer an interesting point of departure. They are introduced as undeniable evidence for Epicurus' position, and at the same time have to guarantee that all the consequences which Plutarch derives from them are indeed relevant. In [2], the reference to Epicurus' conviction that one can never be sure of escaping detection is applied to a similar uncertainty about maintaining the condi-

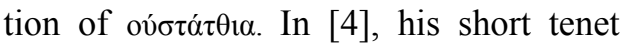

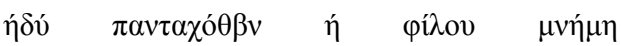

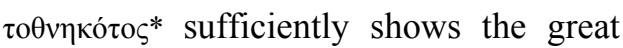
pleasures he renounces by denying the immortality of the soul. In [3], finally, the quotation rather shows his 'inconsistency', being grateful for trivial favours while despising great achievements . 
The three quotations which can be found in the other polemical works are very functional too. 1 have already discussed Plutarch's attack on the Epicurean maxim $\lambda \alpha \dot{\theta} € \beta \hat{\imath} \omega \alpha \varsigma^{*}$ ([7], cf. supra 4.2). In [5], the quotation comes at the very end of a list of Epicurean tenets. The previous doctrines are all paraphrased (even though Plutarch's paraphrase occasionally remains fairly close to Epicurus' own words). By adding one verbatim quotation, Plutarch tries to confirm the picture he just sketched. At the same time, the persuasive force of the whole previous list is added to the culminating quotation. A very interesting example can be found in [6]. Here, Plutarch quotes a particularly nuanced statement of Epicurus. $\mathrm{He}$ is dealing with a tricky problem, where such nuances can make a bad impression, viz. the sage's obedience to law. Epicurus' obvious hesitation to underline such obedience in absolute terms is gefundenes Fressen of course in the anti-Epicurean polemical context of Adversus Colotem. Moreover, Epicurus is using technical terminology ("the unqualified predication is not free from difficulty"), which may hin- der the reader's understanding, but which Plutarch - kindly enough - translates in easier terms ("I shall do it, but I do not wish to admit it"). It is clear that this is a highly biased interpretation of Epicurus' words, but once again, Plutarch's purpose is not to understand Epicurus' hesitations, but to exploit them as much as he can in order to reach his polemical goal.

A particularly interesting case, finally, is the long quotation near the end of De audiendis poetis ([1]). At first sight, Epicurus' view here receives a positive evaluation. It is introduced as an example of the philosophical insights to which poetry can prepare young men. Is this the only verbatim quotation that does not serve a polemical purpose? Does Plutarch forget whom he is quoting here? Perhaps the solution should be sought elsewhere. It is exactly the radicalness and strangeness of the Epicurean view which makes it so interesting for Plutarch in this context. For Plutarch is looking for philosophical tenets which are at odds with widespread convictions. References to Platonic doctrines would be incautious, then, as they could easily

eines lustvollen Lebens der Freundschaft zwar eine hohe Bedeutung beimiBt, dem Wirken in der Offentlichkeit aber ein zuruckgezogenes Leben vorzieht."

On this much discussed passage, see, e.g., R. WestMAn, o.c. [n. 10], 185-189; N. DENYER, 'The Origins of Justice', in: $\Sigma v \zeta \eta$ $\tau \eta \sigma l \varsigma$. Studi sullEpicureismo greco e romano offerti a Marcello Gigante, Napoli, 1983, 145-147; M. ERLER, 'Epikur', in: H. FLASHAR (ed.), Die Philosophie der Antike, Band 4: Die Hellenistische Philosophie (Grundriss der Geschichte der Philosophie, begriindet von Friedrich Ueberweg), Basel, 1994, I, 165; G. SEEL, "Fara il saggio qualcosa che le leggi vietano, sapendo che non sara scoperto?", in: G GianNANTONI - M. GIGANTE (eds.), Epicureismo greco e romano. Atti del Congresso Internazionale. Napoli, 19-26 maggio 1993, Napoli, 1996, I, 341-360. 
lead to a polemical attack on his own philosophy as being at odds with the common conceptions. What Plutarch needs here are "strange" doctrines of other philosophical schools. He could have found them in Stoic philosophy (cf. his treatise De communibus notitiis adversus Stoicos), but no less in that of Epicurus. By quoting Epicurus at length, Plutarch indirectly makes clear how strange the latter's philosophy is. If that is true, the passage should not be understood as an exceptional approval of Epicurus' views, but as subtle polemic.

5.To conclude, this study turns out to yield a rather paradoxical result. A contemporary reader who wishes to gain a deeper insight in Epicurus' socio-political thinking should also be thoroughly familiar with Plutarch. In that sense, an important part of Epicurus' Nachleben will always be closely connected with that of Plutarch. But when the contemporary reader indeed gradually becomes familiar with Plutarch's polemical purposes and eristic strategies, he soon realizes that he often deals with a quite unreliable source. He will never be able to disregard this source completely, to be sure, but he knows that it primarily casts its light on itself, rather than on Epicurus.

Just like Horace, Plutarch finished a monument more lasting than bronze. His monument, which not even centuries could destroy, is constructed by means of innumerable components. It rests on a carefully fashioned (cf. De prof, in virt. 85F-86A) foundation of Platonism. Its superstructure contained several pieces of Epicureanism. These pieces are never added for their own sake, but always play a minor - though essential - part in buttressing the whole edifice. Removing them from the whole will never lead to a complete reconstruction of Epicurus' monument, of which too many pieces have been lost. It will lead, however, to a destruction of that of Plutarch. 